\title{
POLYMORPHISM IN THE DESMID COSMARIUM ABBREVIATUM VAR. MINUS (ZYGNEMAPHYCEAE) AND ITS TAXONOMIC IMPLICATIONS
}

\author{
Carlos E. de M. Bicudo ${ }^{1}$
}

Received: Aug. 5, 1987. Accepted: Oct. 20, 1987.

RESUMO - Relata-se um caso de polimorfismo na alga desmidiácea (Zygnemaphyceae) Cosmarium abbreviatum Raciborski var. minus (West \& West) Krieger \& Gerloff. O material foi coletado de três estações distintas no Lago das Ninféias, que se situa no Parque Estadual das Fontes do Ipiranga, cidade de São Paulo, Brasil. O exame criterioso de aproximadamente 200 indivíduos permitiu relacionar e descrever seis expressões morfológicas e fazer as seguintes observações: 1) para delimitação de espécie e de táxons infra-específicos em desmídias, é absolutamente necessária a análise de amostras populacionais; 2 ) as características morfológicas atualmente utilizadas na delimitação de certas espécies constituidas de individuos de pequeno porte parecem não ter valor taxonômico quando apenas indivíduos isolados são examinados; e 3) devemse tratar com cautela táxons como: Cosmarium angulosum Brébisson var. angulosum f. angulosum, C. abbreviatum Raciborski var. minus (West \& West) Krieger \& Gerloff, C. succisum G.S. West var. jaoi Krieger \& Gerloff, $C$. tinctum Ralfs var. tinctum e $C$. minimum West \& West var. minimum, até que novos estudos confirmem o presente, visto poderem ser apenas expressões morfológicas de C. abbreviatum var. minus.

Palavras-chave: Cosmarium abbreviatum var. minus; desmidia; polimorfismo; sinonímia; Zygnemaphyceae.

\begin{abstract}
Polymorphism in a population of the desmid (Zygnemaphyceae) Cosmarium abbreviatum Raciborski var. minus (West \& West) Krieger \& Gerloff is reported from material collected from 3 stations at the Lily Pond located in the Parque Estadual das Fontes do Ipiranga, São Paulo City, southern Brazil. From the examination of approximately 200 plants, 6 different morphological expressions were described and the following remarks made: 1) a detailed analysis of sample populations is absolutely necessary for the definition of species and infraspecific categories among desmids; 2 ) the morphological characteristics presently used for the delimitation of certain species, which are built up of individuals of very small size, seem to have no great taxonomical significance when only isolated individuals are analysed; and 3) taxa, such as Cosmarium angulosum Bréb. var. angulosum f. angulosum, C. abbreviatum Rac. var. minus (West \& West) Krieg. \& Gerl., C. succisum G.S. West var. jaoi Krieg. \& Gerl., C. tinctum Ralfs var. tinctum, and C. minimum West \& West var. minimum are of doubtful validity and may prove to be merely polymorphic expressions of $C$. abbreviatuin var. minus.
\end{abstract}

Key words: Cosmarium abbreviatum var. minus; desmid; polymorphism; synonymy; Zygnemaphyceae.

${ }^{1}$ Phycology Section, Instituto de Botânica, Caixa Postal 4005 - 01051 - São Paulo-SP - Brasil 


\section{Introduction}

When in 1908 Playfair stated that desmids are polymorphic, and that about $90-95 \%$ of the species already described were to be considered morphological expressions of the remaining $5-10 \%$, he was almost literaly burned in public. Playfair's numbers were of course an exaggeration, but his ideas still have considerable validity. Nobody doubts anymore the existence of polymorphism in desmids, and that it surely has to do with taxonomy.

Studies of polymorphism in species of Cosmarium are represented by the works of Starr $(1954,1958)$ and Tews (1969), which refer to the variability in the radiation, the first two in $C$. turpinii Bréb. and the latter in C. botrytis Men. var. depressum West \& West, and by Kirk \& Cox (1975), which refers to the variability in the form of the semicell outline in C. botrytis Men. in culture; Gerrath (1979a) has studied variability in the morphology of the basal angles of the semicells and pattern of decoration of the cell wall of C. taxichondrum Lund.; and Gerrath (1979b), morphological variation of $C$. quinarium Lund.

The present paper represents the results of a study of a natural population of C. abbreviatum Raciborski var. minus (West \& West) Krieger \& Gerloff.

\section{Material and methods}

The population came from periphyton collection made from 3 different stations in the Lily Pond in the São Paulo City Botanical Garden, State of São Paulo, southern Brazil, on several occasions during the years 1981 and 1982 . The collections were immediately fixed with $4 \%$ formalin and examined with a Zeiss Oberkochen regular microscope. Drawings were made using a camera-lucida attachment.

Cosmarium Abbreviatum Var. Minus (Fig. 1-13)

Cosmarium abbreviatum is one in a large group of species built up of very small individuals measuring somewhat within $8-30 \times 8-30 \mu \mathrm{m}$. It is a relatively common and widely distributed desmid. As originally described (Raciborski, 1885), it is characterized by its cell, about as long as broad or a little wider than long, 10-25 $\times 10-29 \mu \mathrm{m}$, deeply constricted at the middle, the sinus narrow and closed. The semicells are transverse angular-oval and 5-sided, the lower lateral margins diverging and straight to a median, rounded angle which is slightly produced, and the upper margins are convergent, straight or retuse, to a relatively broad, truncate apical margin. The cell wall is smooth. In lateral view, the semicells are broadly oval to nearly rounded. In vertical view, the cell is asymmetrically oval, with broadly rounded poles.

West \& West (1900) described a f. minor, which differs from the typical mostly by its said consistently smaller size $(9-13 \times 8-13 \mu \mathrm{m})$, and by the narrowly rounded lateral angles which are never produced. Krieger \& Gerloff (1969) raised it to the varietal level. 


\section{Observations}

The population examined showed variability in the depth (Fig. 1, 4), and shape and aperture of the sinus which varied from linear and closed (Fig. 3) to acutangular (Fig. 4); in the shape of the lateral margins of the semicells which varied in the presence and position of a median angular inflation (Fig. 1-2, 4-5); and in the shape of the semicell outline which consequently varied from sub-elliptical (Fig. 4) to sub-rectangular (Fig. 5). As a result, the following 6 main morphological expressions (forms) could be detected:

Form 1 - Semicells transversely angular-oval, lower part of lateral margins straight of almost so, broadly divergent, forming a rounded median angle, upper part usually straight, rarely slightly retuse, convergent, upper angle obtuse, apex broadly truncate, straight or very slightly retuse at the middle (Fig. 2).

Form 2 - Semicells transversely sub-hexagonal, lower and upper parts of lateral margins about equal in length, straight or very slightly convex, median angle rounded, upper angle obtuse, apex broadly truncate, straight (Fig. 1).

Form 3 - Semicells sub-trapeziform, basal angles broadly rounded, lateral margins slightly retuse at the middle, convergent, apex broadly truncate, straight or very slightly convex (Fig. 6).

Form 4 - Semicells transversely sub-elliptic, angles rounded or slightly truncate, apex slightly convex; sinus open, acute-angled (Fig. 4).

Form 5 - Semicells transversely sub-rectangular, basal and upper angles subrectangular, the upper ones usually more rounded, lateral margins faintly convex, sub-parallel, apex broadly truncate, slightly convex; sinus open, acuteangled (Fig. 5).

Form 6 - Semicells transversely sub-hexagonal, lower and upper parts of lateral margins unequal in length, the lower ones shorter than the upper, straight, median and upper angles obtuse, apex broadly truncate, straight (Fig. 3).

If single individuals are taken for taxonomic identification, and if we follow the usual, classic procedures of taxonomic identification by comparison of illustrations, form 1 would be considered to be a representative of Cosmarium abbreviatum Raciborski var. minus (West \& West) Krieger \& Gerloff; form 2 of Cosmarium angulosum Brébisson var. angulosum f. angulosum; form 3 of Cosmarium succisum G.S. West var. jaoi Krieger \& Gerloff; form 4 of Cosmarium tinctum Ralfs var. tinctum; form 5 of Cosmarium minimum West \& West var. minimum; and form 6 also of Cosmarium abbreviatum Raciborski var. minus (West \& West) Krieger \& Gerloff.

Clear differentiation of these taxa was complicated by the fact that a complete range of intermediate forms was found. Hence the identification of individual specimens was difficult. Frequently, in the same individual the 2 semicells are morphologically so different that it was impossible to apply just one name to the plant. 
Indeed, each semicell could be identified as a different species (dichotypical individuals).

Obviously we are dealing with a single population showing considerable variation among individuals. It is impossible to say that this or that individual is more typical than some others. Individual variation only shows which characteristics may safely be used in taxonomic studies, and which are too variable to be used for this purpose. In the present case the shape of the lateral margins of the semicells and consequently that of the semicell outline when only isolated individuals are considered seem to be of minor significance, because no pronounced breaks in these characteristics are noticeable. We must consider them, and chiefly their variation, within the population. For this reason, such characteristics alone should not be considered for delimitation of species, or even varieties.

Another aspect that should be discussed is the difference of observation by the various workers. All taxa above mentioned are constituted by individuals of very small size (8-28 $\mu \mathrm{m}$ in lenght and 7-22 $\mu \mathrm{m}$ in breadth), and the slightest slip of the pencil during the camera-lucida sketching of the material for identification may - or certainly will - lead to morphological "deviations" from what is mentioned in the literature to be typical for that taxon. This will consequently lead to different taxonomical interpretations of that same material. Fig. 7-13 represent various individual interpretations from different students at the Phycology Section of the Instituto de Botânica of the very same plant and using the same microscope and drawing equipment.

\section{Conclusions}

After careful examination of the almost 200 plants studied, the following remarks can be made:

1. It is hazardous, perhaps impossible, to define species, infraspecific categories, and even genera among desmids without a detailed analysis of sample populations, in order to know the morphological variation of the many characteristics commonly used in taxonomy, as well as the limit of confidence in their use.

2. The delimitation of taxa such as Cosmarium angulosum Brébisson var. angulosum f. angulosum, Cosmarium abbreviatum Raciborski var. minus (West \& West) Krieger \& Gerloff, Cosmarium succisum G.S. West var. jaoi Krieger \& Gerloff, Cosmarium tinctum Ralfs var. tinctum, and Cosmarium minimum West \& West var. minimum, all built up of very small sized individuals, is today based fundamentally on the shape of the lateral margins of the semicells and consequently on that of the semicell outline. Such morphological characteristics, instead of being universally accepted, seem to have no great taxonomical significance when only isolated individuals are analysed. We must consider the variation spectrum of these characteristics within the population. 
3. It is quite probable - and further studies can and must confirm the present one - that the taxa Cosmarium angulosum Brébisson var. angulosum f. angulosum, Cosmarium abbreviatum Raciborski var. minus (West \& West) Krieger \& Gerloff, Cosmarium succisum G.S. West var. jaoi Krieger \& Gerloff, Cosmarium tinctum Ralfs var. tinctum, and Cosmarium minimum West \& West var. minimum are merely polymorphic expressions of a single taxonomic category. If this is true, such taxa may be considered synonymous from the nomenclatural viewpoint.

4. There obviously are - and we must consider them - differences in observation by the various students. In taxa constituted by individuals of very small size, the slightest slip of the pencil during the camera-lucida sketching of the material for identification may lead to "morphological variations", and consequently to the giving of different names to the very same plant.

\section{Acknowledgement}

The author thanks Mr. Alasdair G. Burman for revision of the English text.

\section{Bibliographic references}

GERRATH, J.F. 1979a. Polymorphism in the desmid Cosmarium taxichondrum Lundell. Br. phycol. J., London, 14(3): 211-217, fig. 1-2.

1979b. Morphological observations on the desmid Cosmarium quinarium Lundell from Pudding Pond, New Hampshire. Nova Hedwigia, Braunschweig, 31(1-2): 519-524, fig. 1-20.

KIRK, W.L. \& COX, E.R. 1975. Observations on polymorphism in the green alga Cosmarium botrytis Menegh. (Desmidiaceae). Phykos, New Delhi, 14(1-2): 35-40, fig. 1-7.

KRIEGER, W. \& GERLOFF, J. 1969. Die Gattung Cosmarium. Lehre: J. Cramer. Vol. 3-4, p. $241-410$, pl. $43-71$.

RACIBORSKI, M. 1885. De nonnulis desmidiaceis novis vel minus cognitis, quae in Poloniae inventae sunt. Pam. Wydz. Akad. Umiejet, Krakow, 10: 57-100, pl. 10-14.

STARR, R.C. 1954. Heterothallism in Cosmarium botrytis var. subtumidum. Am. J. Bot., Lancaster, PA, 41(8): 601-607, fig. 1-30, tab. 1.

1958. The production and inheritance of the triradiate form in Cosmarium turpinii. Am. J. Bot., Lancaster. PA, 45(3): 243-248, fig. 1-21.

TEWS, L.L. 1969. Dimorphism in Cosmarium botrytis var. depressum. J. Phycol., Lawrence, KA, 5(3): 270-271, fig. 1-4.

WEST, W. \& WEST, G.S. 1900. The algal-flora of Yorkshire, a complete account of the know freshwater algae of the Country, with many notes on their affinities and distribution. Trans. Yorks. Nat. Un., Leeds, 5(22): 1-52; (23): 53-100; (25): 101-164; (27): 165-239. 

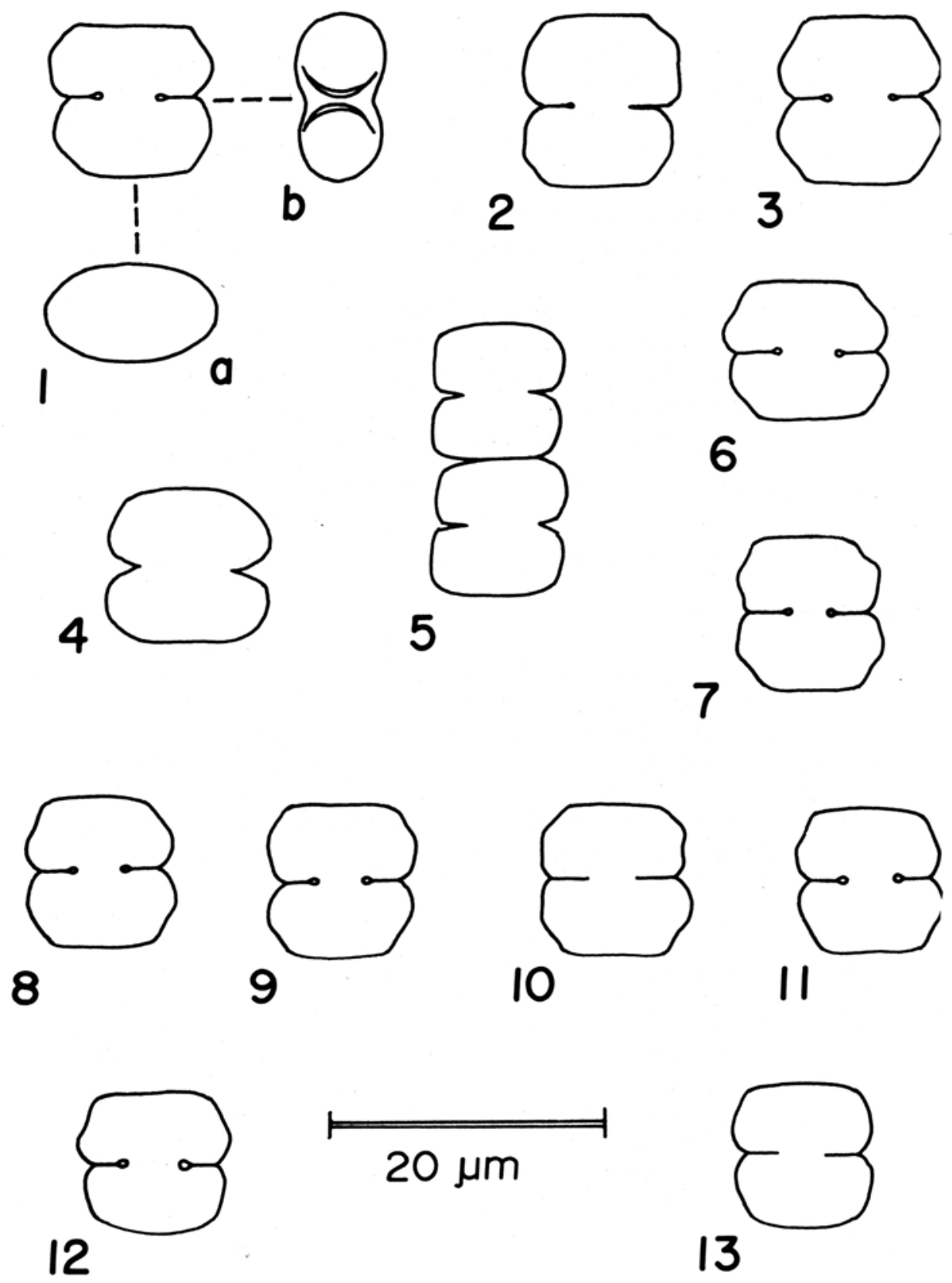

Fig. 1-13. Cosmarium abbreviatum Raciborski var. minus (West \& West) Krieger \& Gerloff. Fig. 1. Typical form; a. vertical view of a semicell; b. lateral view. Fig. 2-6. Morphological expressions seen the population sample studied. Fig. 7-13. Individual interpretations of the same plant by different students at the laboratory. 